\title{
Structure-based scaffold repurposing towards the discovery of novel cholinesterase inhibitors
}

Satish N. Dighe*, Mangapathiraju Tippana, Suzannah van Akker, Trudi A. Collet

Institute of Health \& Biomedical Innovation, Queensland University of Technology, 60 Musk Avenue, Kelvin Grove, Brisbane, QLD, Australia 4059.

*Corresponding author. Email: sdighe2008@gmail.com 
Table S1. Compounds 1-25: supplier IDs and chemical structures.

\begin{tabular}{|c|c|c|}
\hline $\begin{array}{c}\text { Comp. } \\
\text { No. }\end{array}$ & Supplier ID & Structures \\
\hline 1 & $\begin{array}{c}\text { Princeton Biomolecular } \\
\text { Research } \\
\text { OSSK_733122 }\end{array}$ & \\
\hline 2 & $\begin{array}{l}\text { ChemDiv } \\
4378-0494\end{array}$ & \\
\hline 3 & $\begin{array}{l}\text { ChemDiv } \\
\text { K284-1072 }\end{array}$ & \\
\hline 4 & $\begin{array}{c}\text { Princeton Biomolecular } \\
\text { Research } \\
\text { OSSL_680030 }\end{array}$ & \\
\hline 5 & $\begin{array}{l}\text { ChemDiv } \\
\text { C090-0455 }\end{array}$ & \\
\hline
\end{tabular}




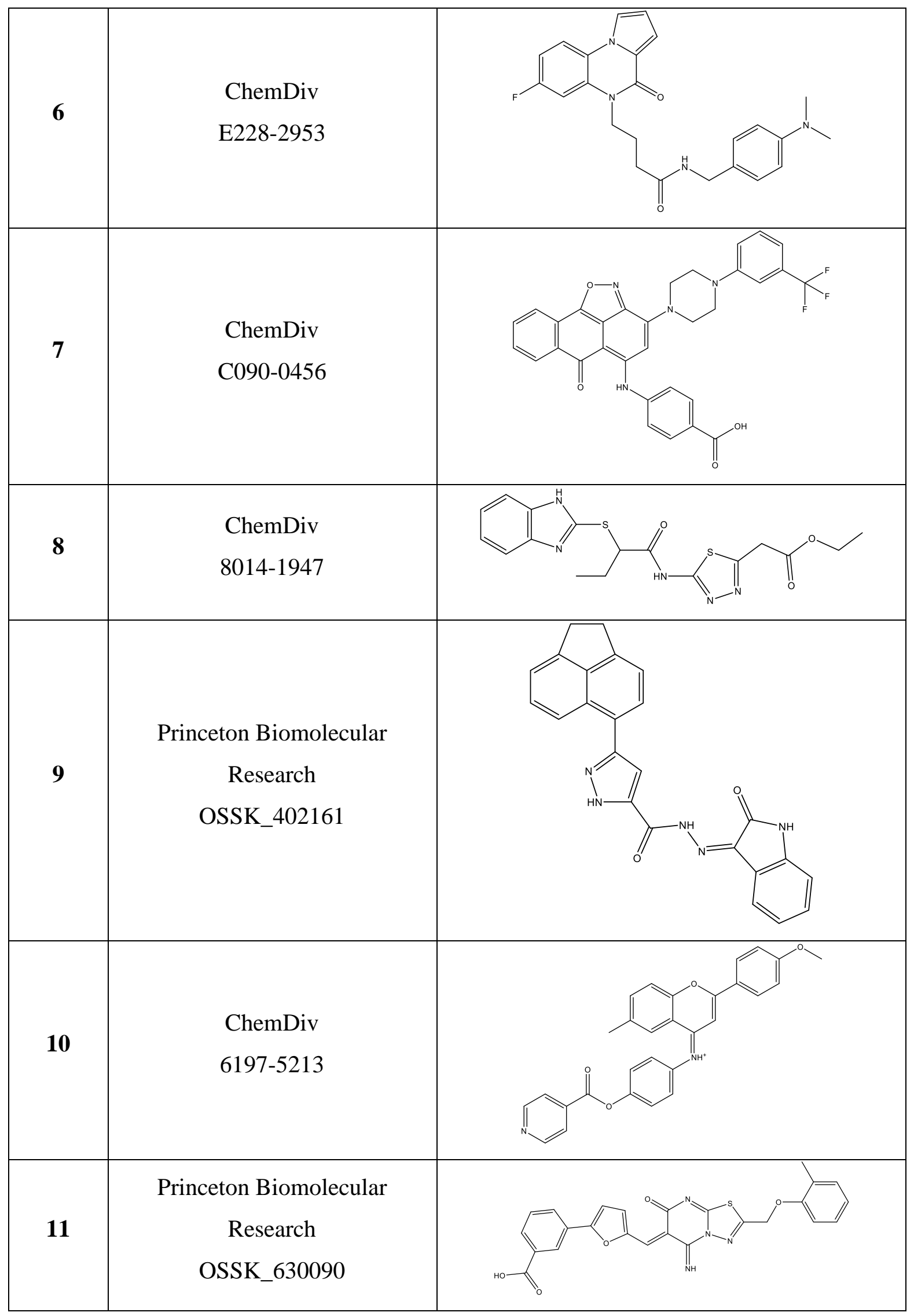




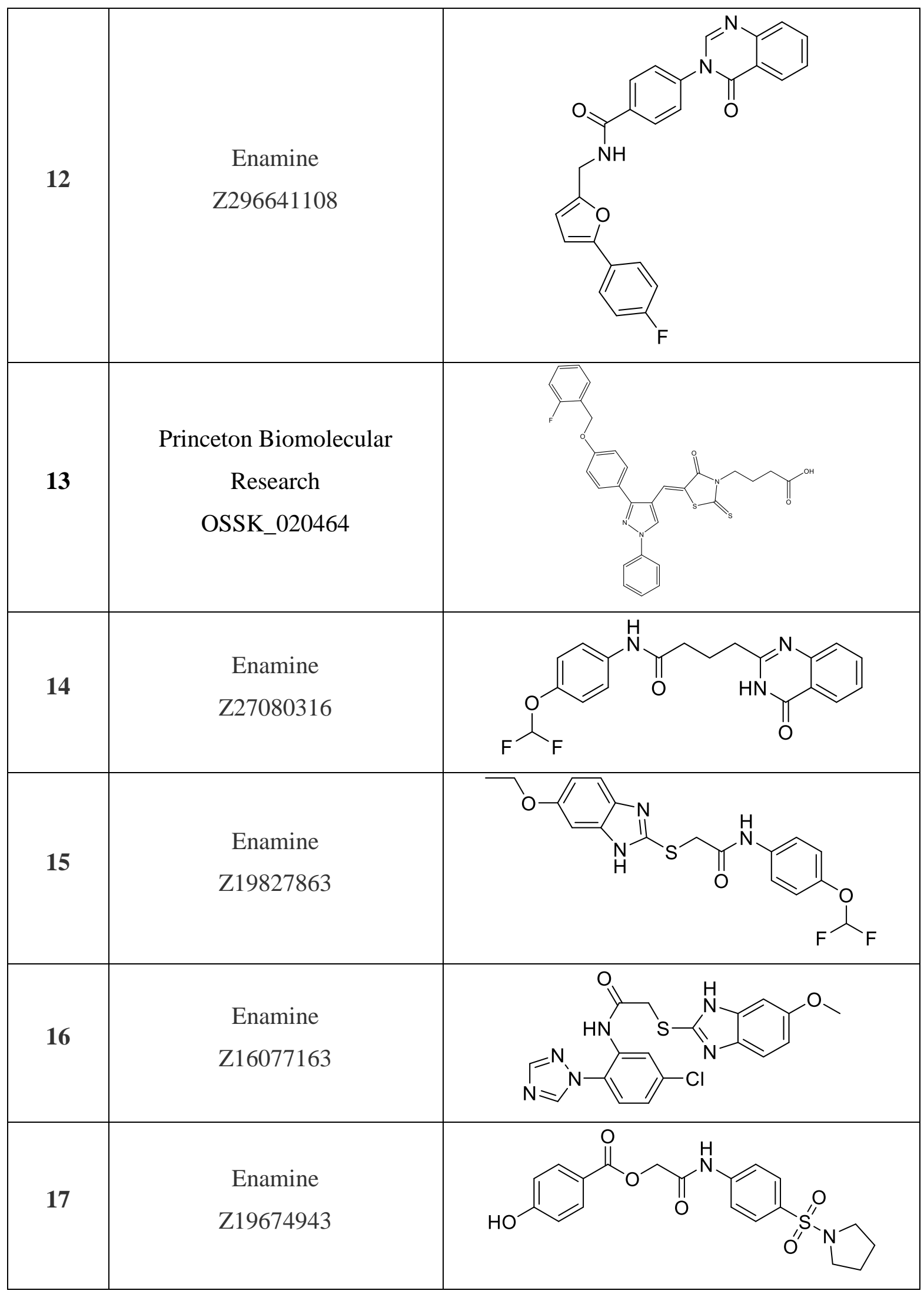




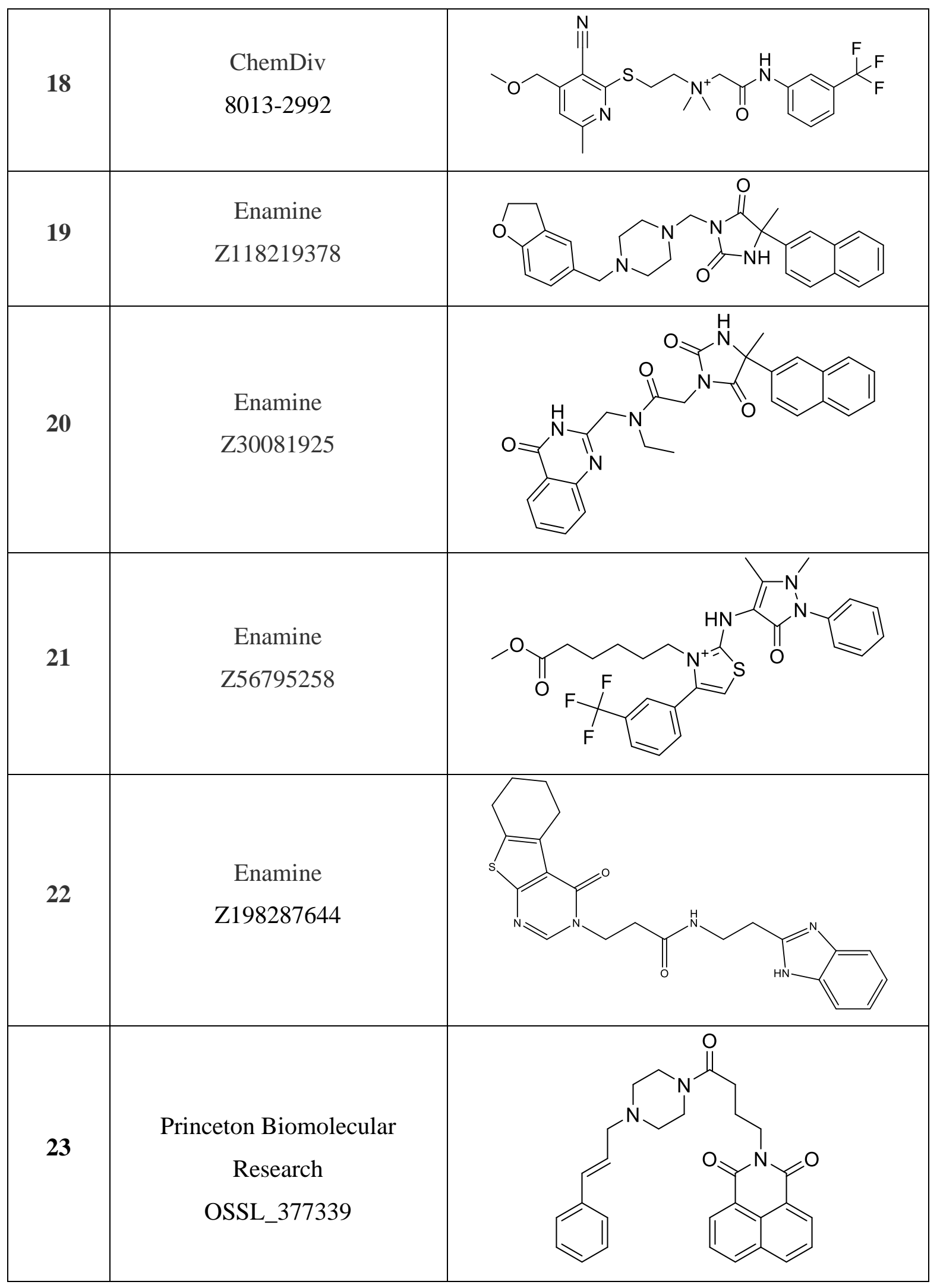




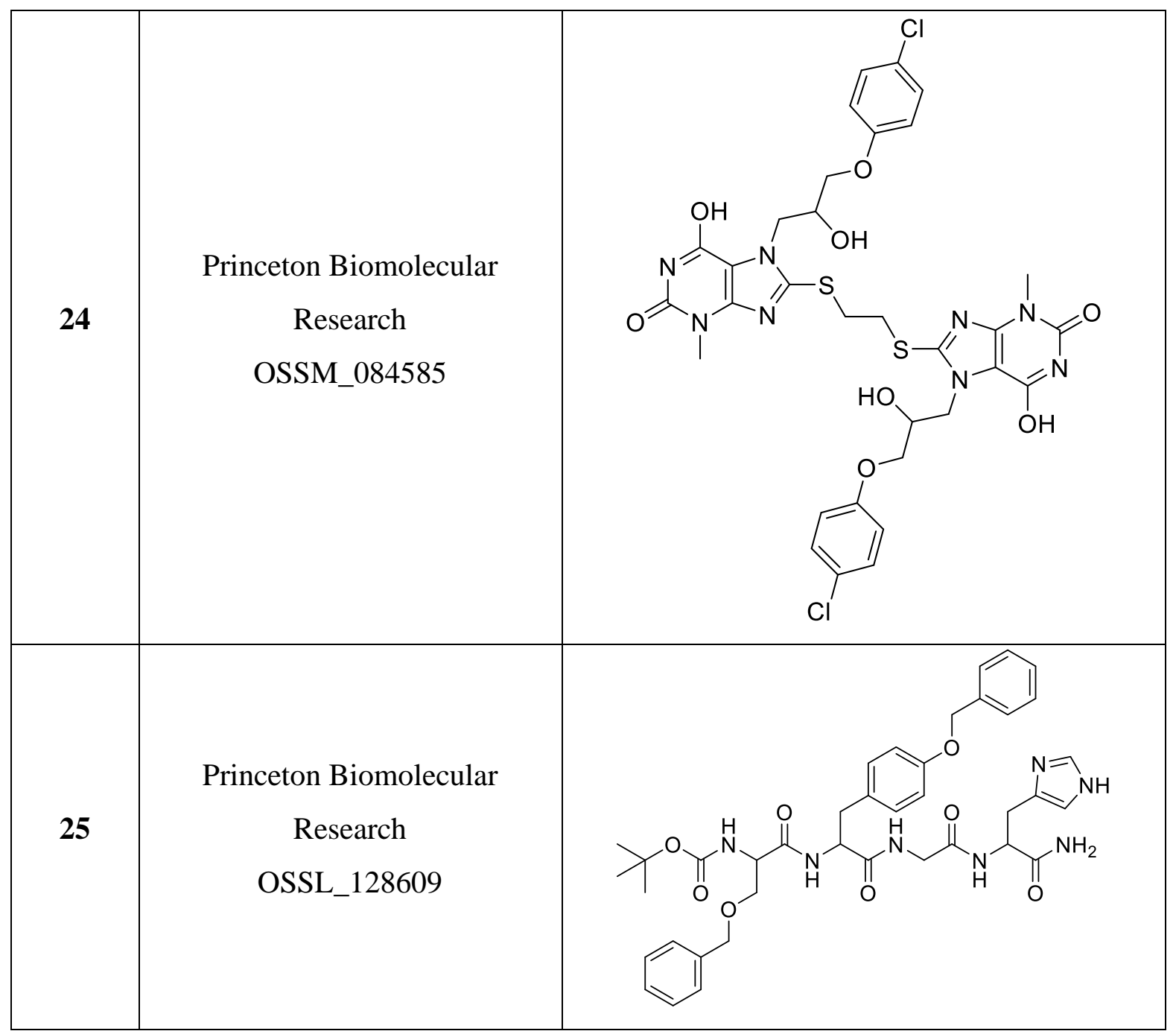


A) Docking models for compounds 5, 7, 9, and 13 within the active site of hAChE (PDB entry 4EY7).

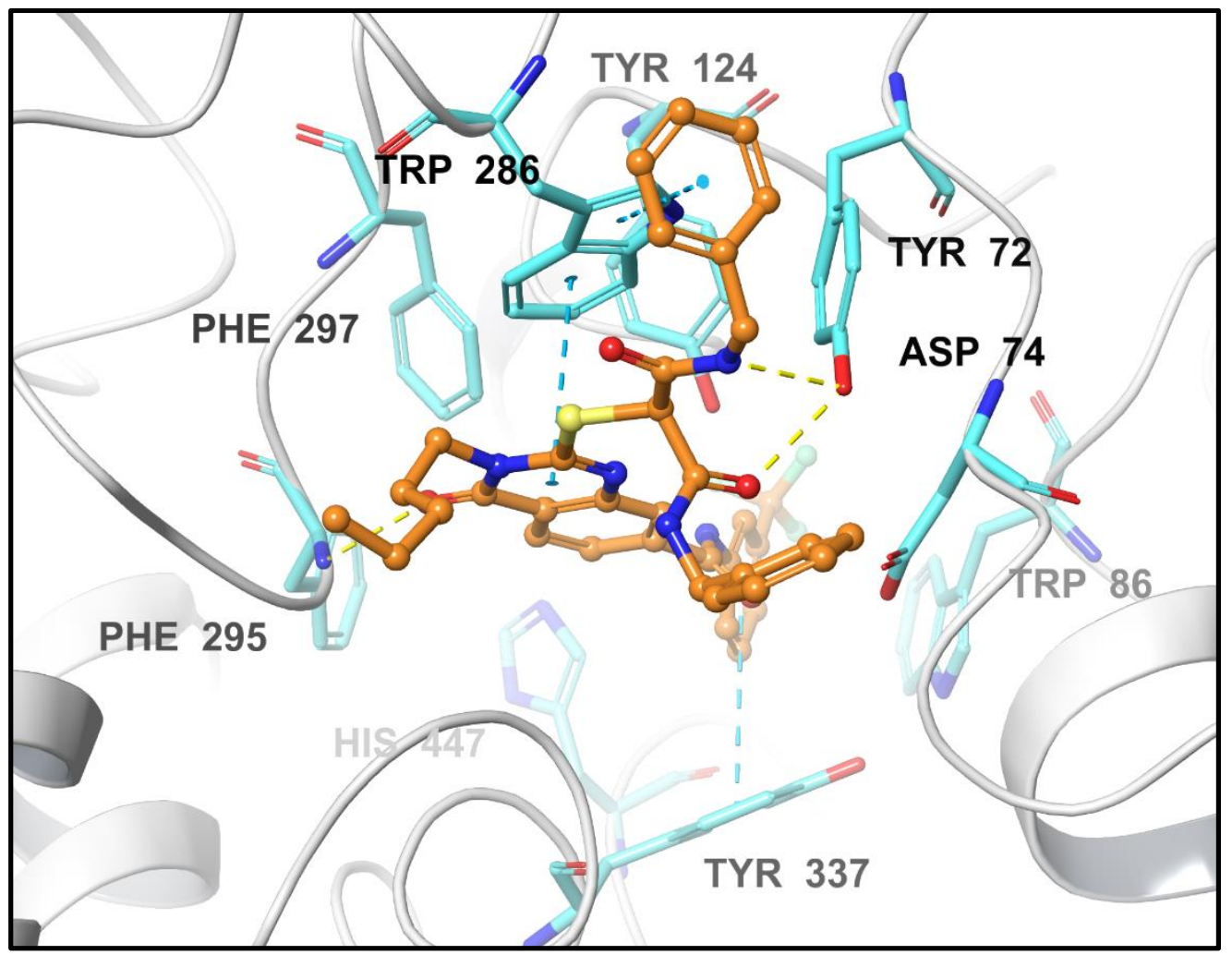

Figure S1: Additional image for compound $\mathbf{3}$ within the active site of hAChE.

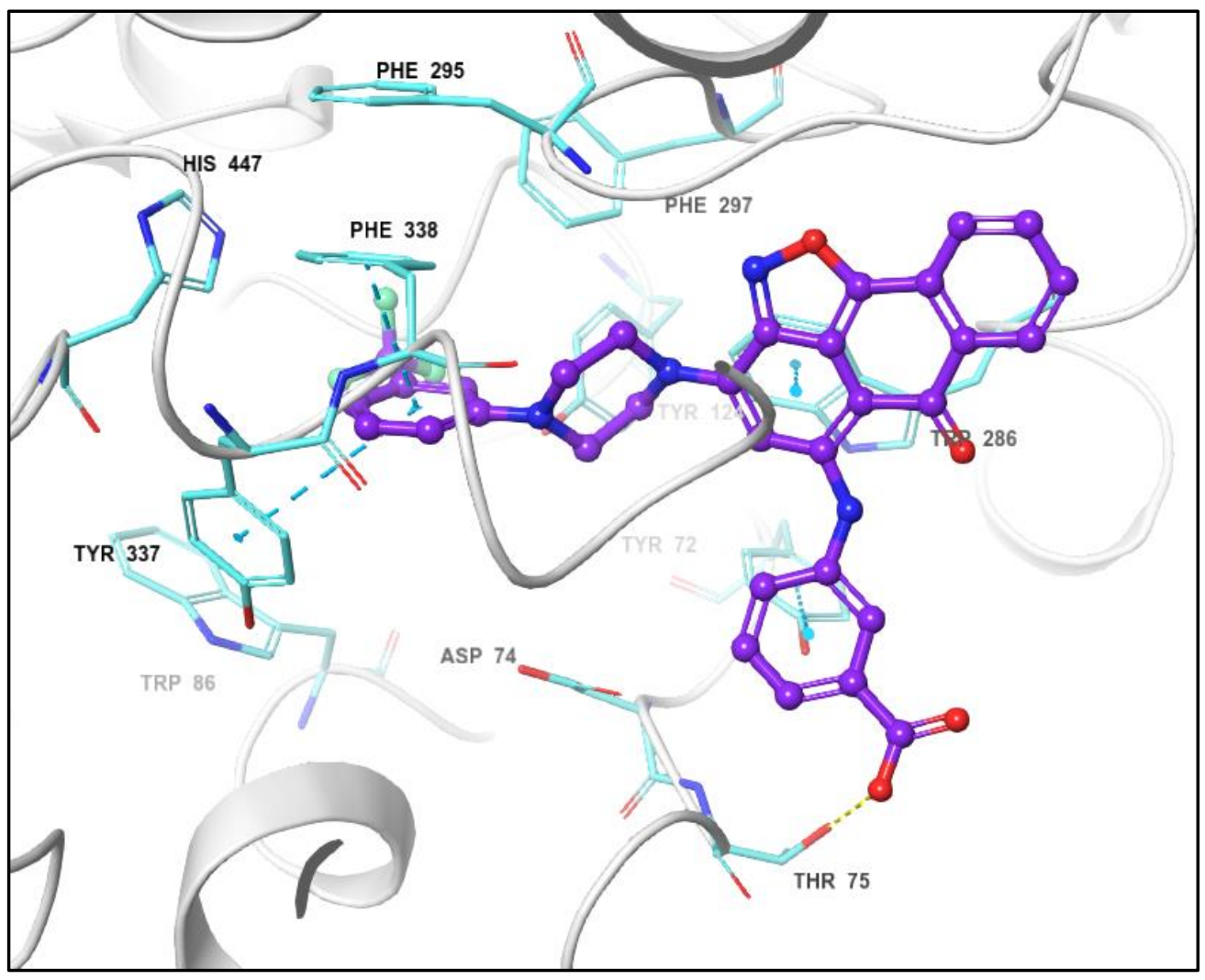

Figure S2: Compound $\mathbf{5}$ within the active site of hAChE. 


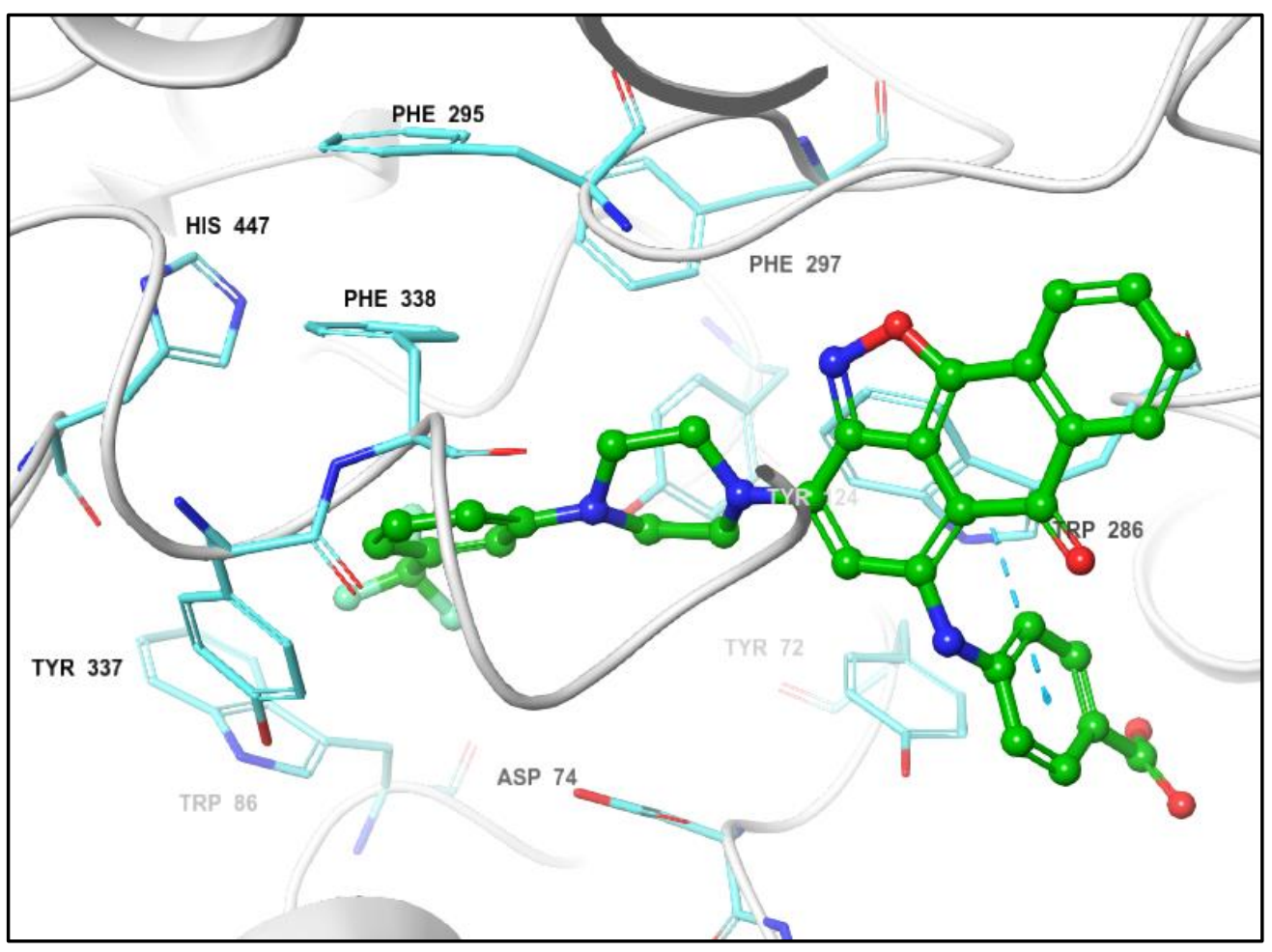

Figure S3: Compound 7 within the active site of hAChE.

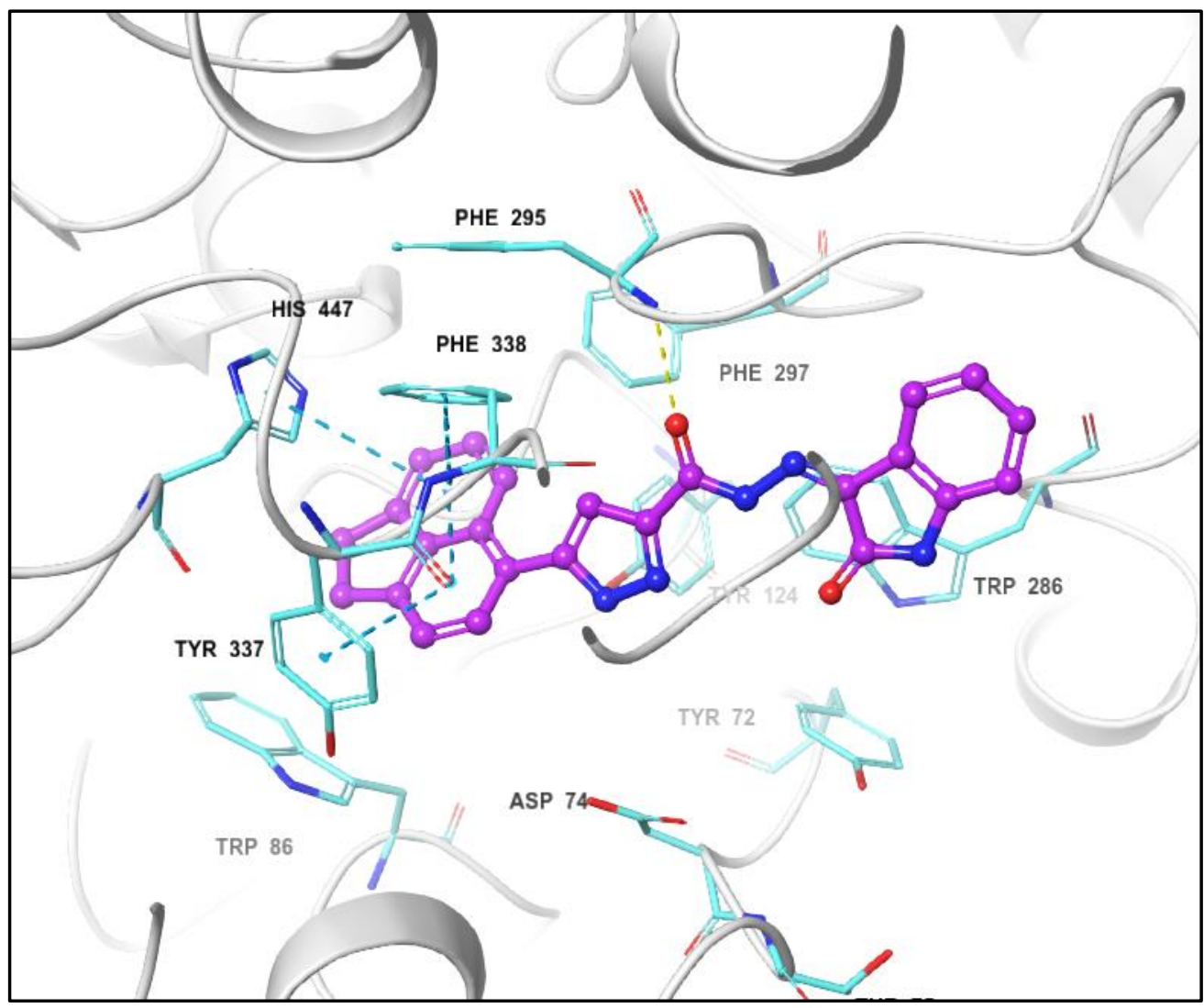

Figure S4: Compound 9 within the active site of hAChE. 


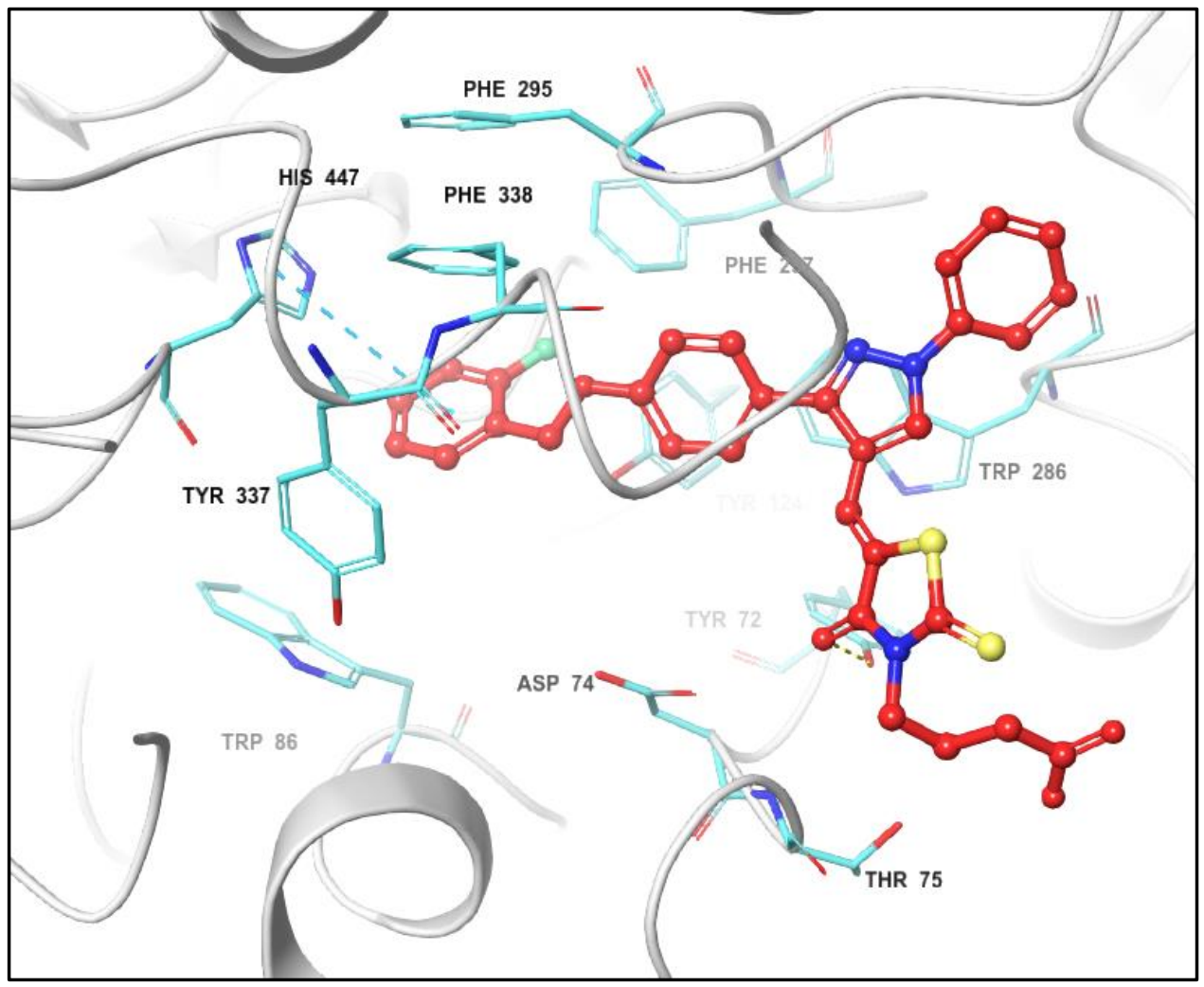

Figure S5: Compound 13 within the active site of hAChE.

B) Comparison of the docked pose and crystal structure pose.

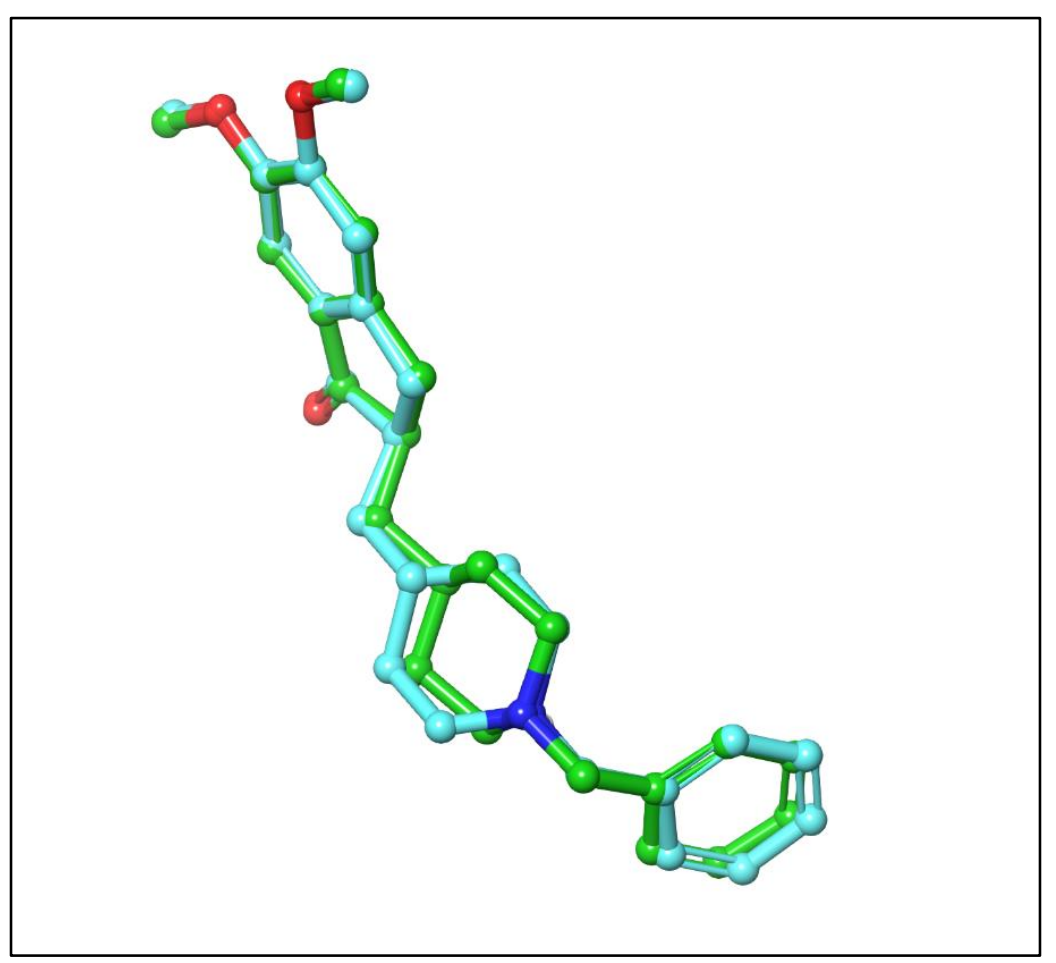

Figure S6: Comparison of the docked pose (in green) and crystal structure pose (in turquoise) for a ligand in AChE. 


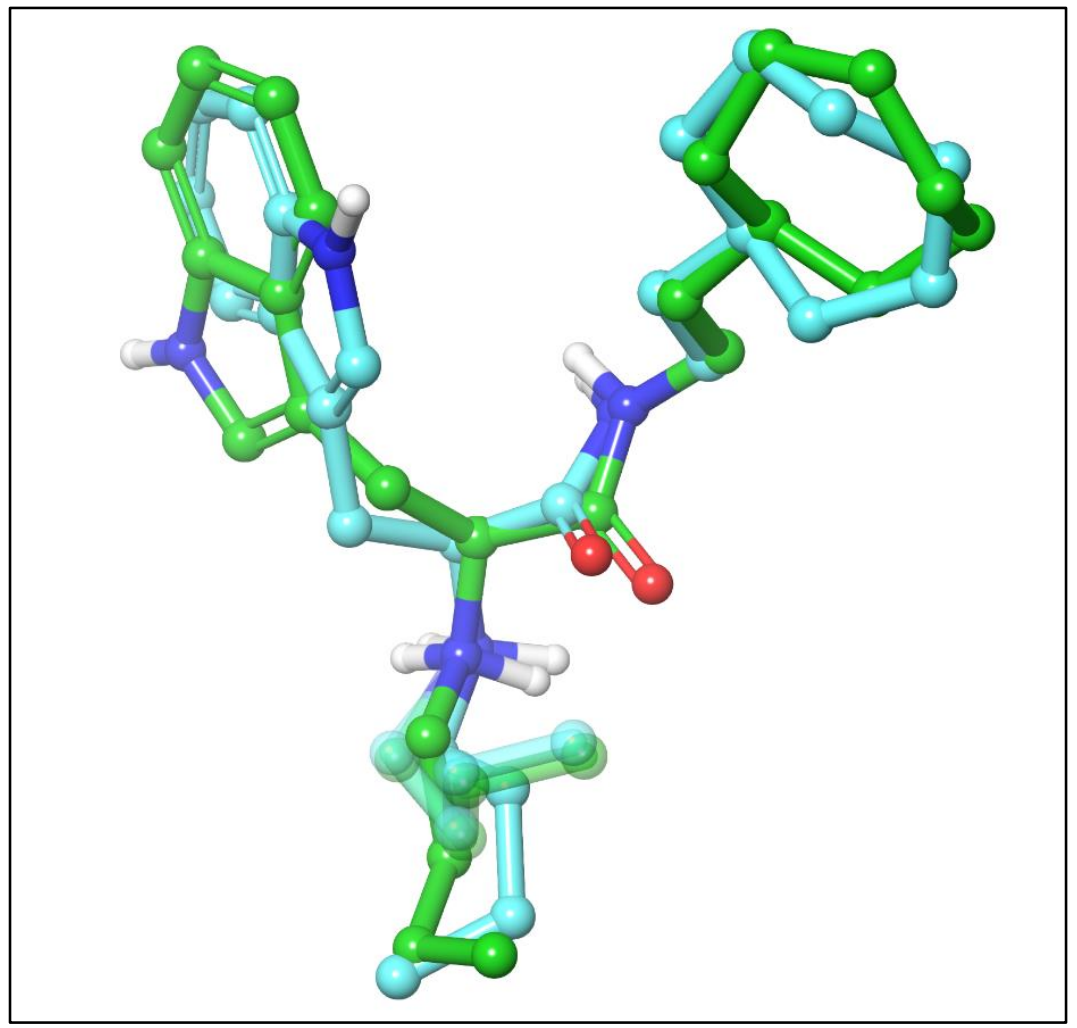

Figure S7: Comparison of the docked pose (in green) and crystal structure pose (in turquoise) for a ligand in BuChE.

C) Comparison of the docked poses of compound 3 within the active site of Torpedo californica AChE (TcAChE) and hAChE.

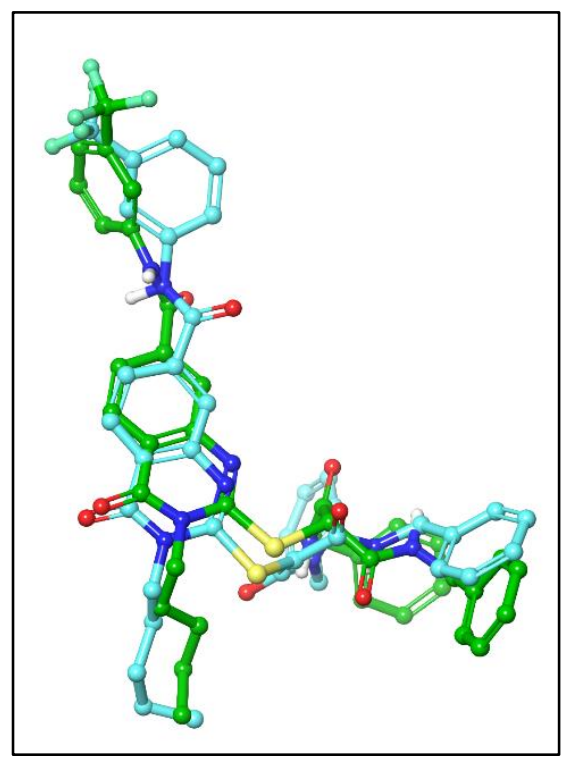

Figure S8: Superimposition of the docked pose of compound $\mathbf{3}$ in $T c \mathrm{AChE}$ (in turquoise) and $\mathrm{hAChE}$ (in green). 


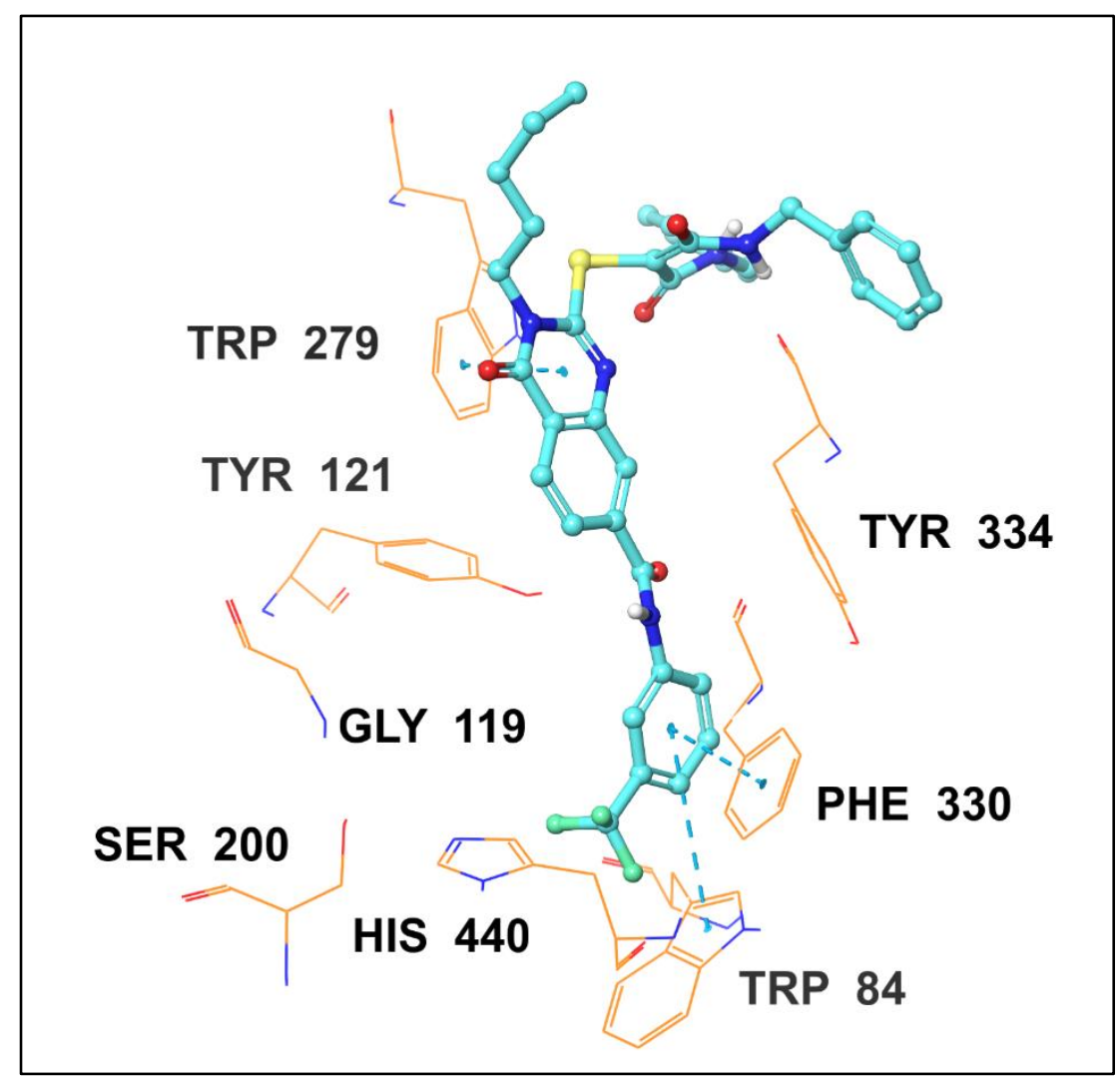

Figure S9: Docked pose of compound $\mathbf{3}$ in the active site of TcAChE.

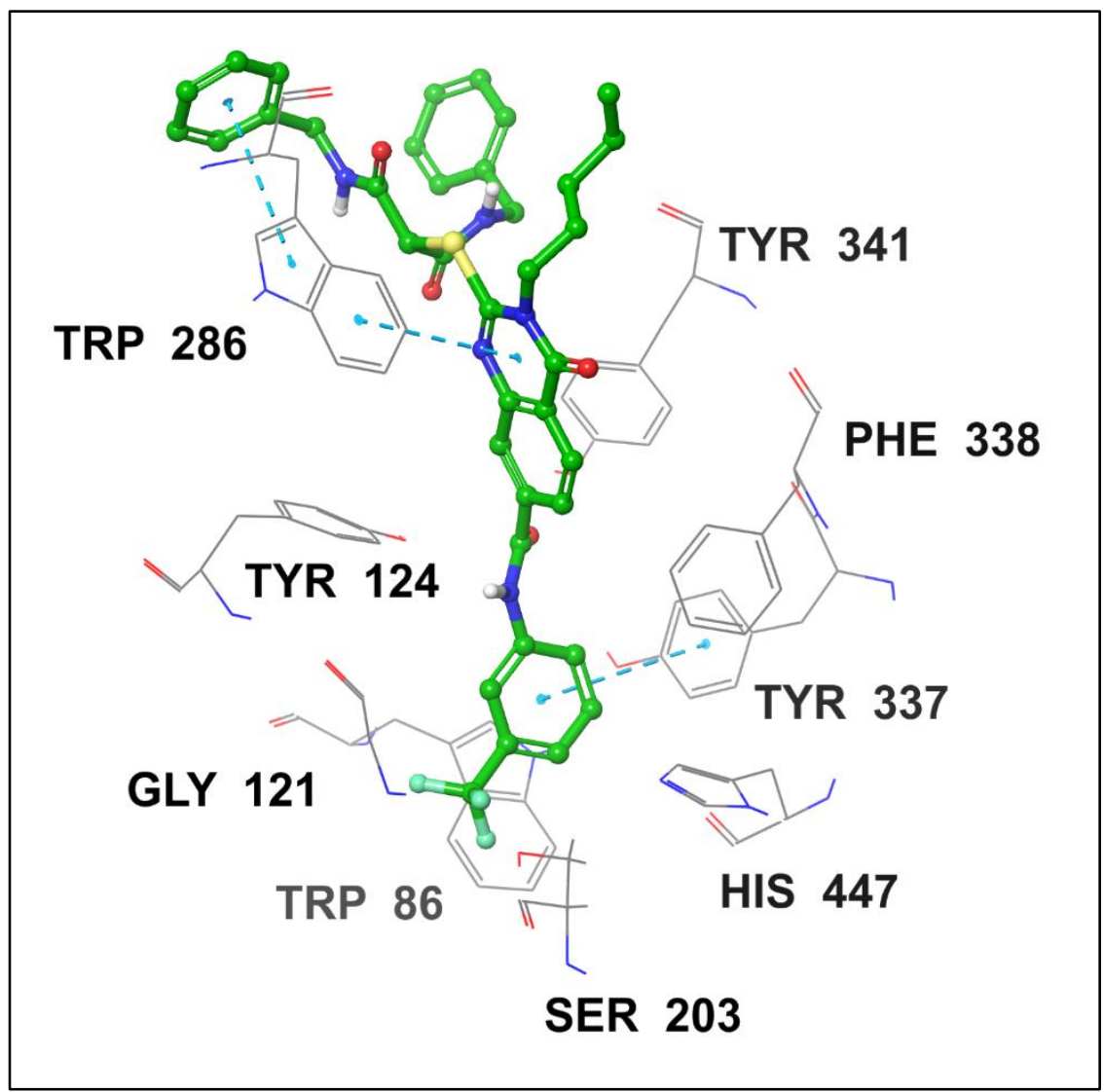

Figure S10: Docked pose of compound 3 in the active site of hAChE. 


\section{D) Characterization data for compounds 3, 5, 7, 9, 13 and 18.}

\section{Compound 3}

${ }^{1} \mathrm{H}$ NMR (600 MHz, DMSO-d6): $\delta=0.91(\mathrm{t}, 3 \mathrm{H}), 1.37-1.39(\mathrm{~m}, 4 \mathrm{H}), 1.76(\mathrm{t}, 2 \mathrm{H}), 4.09-4.12$ $(\mathrm{m}, 2 \mathrm{H}), 4.32-4.40(\mathrm{~m}, 4 \mathrm{H}), 5.50(\mathrm{~s}, 1 \mathrm{H}), 7.14-7.24(\mathrm{~m}, 9 \mathrm{H}), 7.50(\mathrm{~d}, 1 \mathrm{H}), 7.65(\mathrm{t}, 1 \mathrm{H}), 7.97(\mathrm{~s}$, 1H), $8.00(\mathrm{~d}, 1 \mathrm{H}), 8.08(\mathrm{~d}, 1 \mathrm{H}), 8.22-8.26(\mathrm{~m}, 2 \mathrm{H}), 8.88(\mathrm{t}, 2 \mathrm{H}), 10.89(\mathrm{~s}, 1 \mathrm{H})$. MS: calculated for $\mathrm{C}_{38} \mathrm{H}_{35} \mathrm{~F}_{3} \mathrm{~N}_{5} \mathrm{O}_{4} \mathrm{~S}^{-}[\mathrm{M}-\mathrm{H}]^{-}:$: 714.24, found 714.33 .

\section{Compound 5}

${ }^{1} \mathrm{H}$ NMR (600 MHz, DMSO-d6): $\delta=3.55(\mathrm{t}, 4 \mathrm{H}), 4.07$ (s, 4H), $6.34(\mathrm{~s}, 1 \mathrm{H}), 7.09(\mathrm{~d}, 1 \mathrm{H}), 7.22$ (s, 1H), $7.24(\mathrm{~d}, 1 \mathrm{H}), 7.45(\mathrm{t}, 1 \mathrm{H}), 7.64(\mathrm{t}, 1 \mathrm{H}), 7.71(\mathrm{t}, 1 \mathrm{H}), 7.79-7.87(\mathrm{~m}, 3 \mathrm{H}), 8.02(\mathrm{~s}, 1 \mathrm{H})$, $8.17(\mathrm{~d}, 1 \mathrm{H}), 8.45(\mathrm{~d}, 1 \mathrm{H}), 11.77(\mathrm{~s}, 1 \mathrm{H})$. MS: calculated for $\mathrm{C}_{32} \mathrm{H}_{22} \mathrm{~F}_{3} \mathrm{~N}_{4} \mathrm{O}_{4}{ }^{-}[\mathrm{M}-\mathrm{H}]^{-}: 583.16$, found 583.25.

\section{Compound 7}

${ }^{1} \mathrm{H}$ NMR (600 MHz, DMSO-d6): $\delta=3.59(\mathrm{t}, 4 \mathrm{H}), 4.15(\mathrm{~s}, 4 \mathrm{H}), 6.55(\mathrm{~s}, 1 \mathrm{H}), 7.09(\mathrm{~d}, 1 \mathrm{H}), 7.23$ (s, 1H), $7.26(\mathrm{~d}, 1 \mathrm{H}), 7.47(\mathrm{t}, 1 \mathrm{H}), 7.65(\mathrm{~d}, 2 \mathrm{H}), 7.76(\mathrm{t}, 1 \mathrm{H}), 7.88(\mathrm{t}, 1 \mathrm{H}), 8.05(\mathrm{~d}, 2 \mathrm{H}), 8.23(\mathrm{~d}$, $1 \mathrm{H}), 8.49(\mathrm{~d}, 1 \mathrm{H}), 11.89(\mathrm{~s}, 1 \mathrm{H})$. MS: calculated for $\mathrm{C}_{32} \mathrm{H}_{22} \mathrm{~F}_{3} \mathrm{~N}_{4} \mathrm{O}_{4}{ }^{-}[\mathrm{M}-\mathrm{H}]^{-}:$: 583.16, found 583.25.

\section{Compound 9}

${ }^{1} \mathrm{H}$ NMR (600 MHz, DMSO-d6): $\delta=3.43$ (s, 4H), 6.96 (d, 1H), 7.12 (t, 1H), 7.19 (s, 1H), 7.39$7.45(\mathrm{~m}, 3 \mathrm{H}), 7.59(\mathrm{t}, 1 \mathrm{H}), 7.63(\mathrm{~d}, 1 \mathrm{H}), 7.68(\mathrm{~d}, 1 \mathrm{H}), 7.81(\mathrm{~d}, 1 \mathrm{H}), 11.29(\mathrm{~s}, 1 \mathrm{H}), 14.04(\mathrm{~s}, 1 \mathrm{H})$ 14.19 (s, 1H). MS: calculated for $\mathrm{C}_{24} \mathrm{H}_{16} \mathrm{~N}_{5} \mathrm{O}_{2}{ }^{-}[\mathrm{M}-\mathrm{H}]^{-}:$: 406.13, found 406.25.

\section{Compound 13}

${ }^{1} \mathrm{H}$ NMR (600 MHz, DMSO-d6): $\delta=1.89$ (m, 2H), 2.29 (t, 2H), 4.07 (t, 2H), 5.25 (s, 1H), 7.24-7.30 (m, 4H), 7.42-7.47 (m, 2H), 7.55-7.63 (m, 6H), $8.06(\mathrm{~d}, 2 \mathrm{H}), 8.80(\mathrm{~s}, 1 \mathrm{H}) . \mathrm{MS}$ : calculated for $\mathrm{C}_{30} \mathrm{H}_{23} \mathrm{FN}_{3} \mathrm{O}_{4} \mathrm{~S}_{2}^{-}[\mathrm{M}-\mathrm{H}]^{-}:$572.11, found 572.17. 


\section{Compound 18}

${ }^{1} \mathrm{H}$ NMR (600 MHz, DMSO-d6): $\delta=2.56$ (s, 3H), $3.38(\mathrm{t}, 3 \mathrm{H}), 3.39$ (s, 6H), 3.75 (m, 2H), 3.86 $(\mathrm{m}, 2 \mathrm{H}), 4.52(\mathrm{~s}, 2 \mathrm{H}), 4.55(\mathrm{~s}, 2 \mathrm{H}), 7.28(\mathrm{~s}, 1 \mathrm{H}), 7.50(\mathrm{~d}, 1 \mathrm{H}), 7.61(\mathrm{t}, 1 \mathrm{H}), 7.79(\mathrm{~d}, 1 \mathrm{H}), 8.15$ (s, $1 \mathrm{H}), 11.46$ (s, 1H). MS: calculated for $\mathrm{C}_{22} \mathrm{H}_{27} \mathrm{~F}_{3} \mathrm{~N}_{4} \mathrm{O}_{2} \mathrm{~S}^{+}[\mathrm{M}+\mathrm{H}]^{+}$: 468.18, found 468.17. 
D) NMR and Mass spectra for compounds 3, 5, 7, 9, 13, and 18

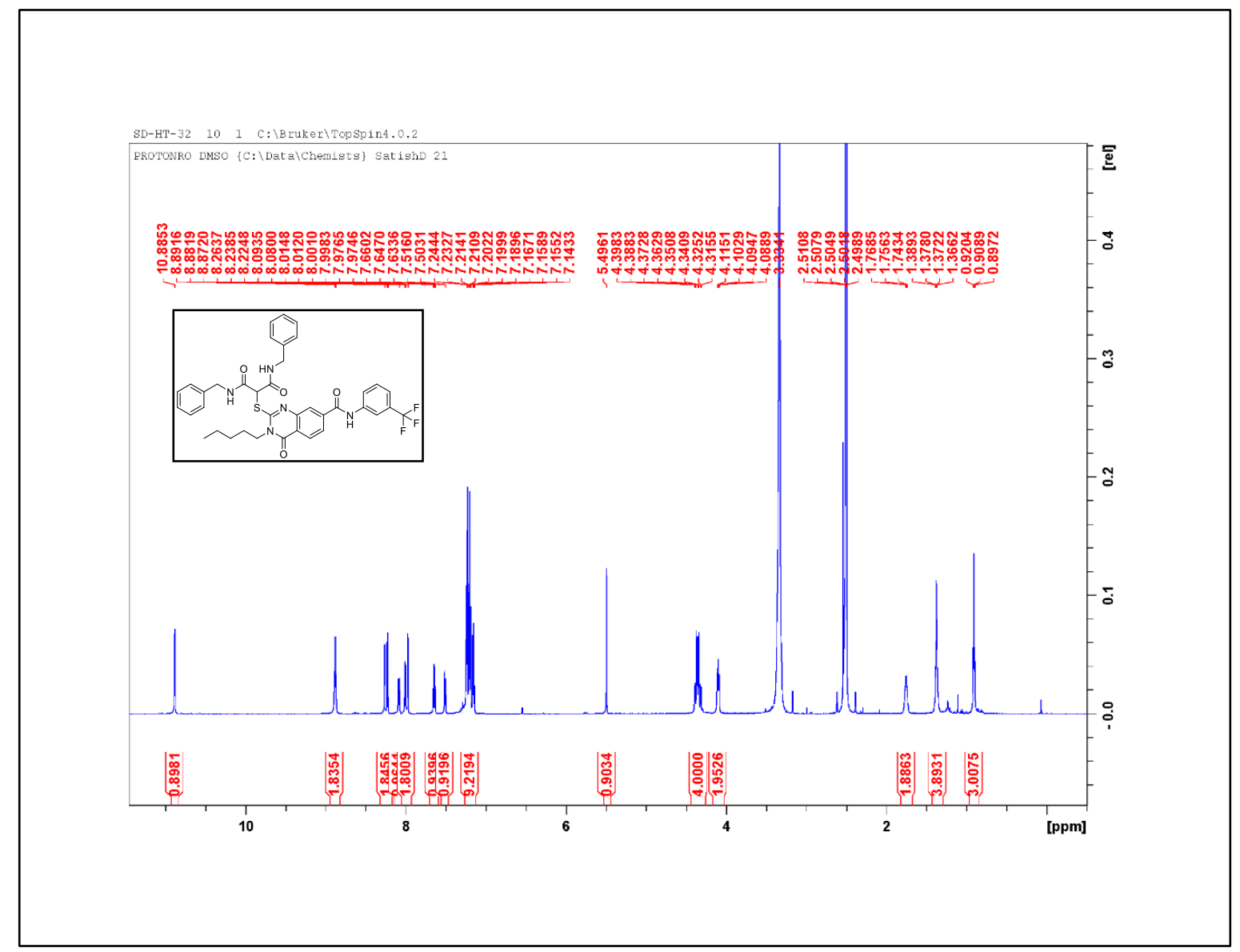

Figure S11: NMR spectrum of compound 3.

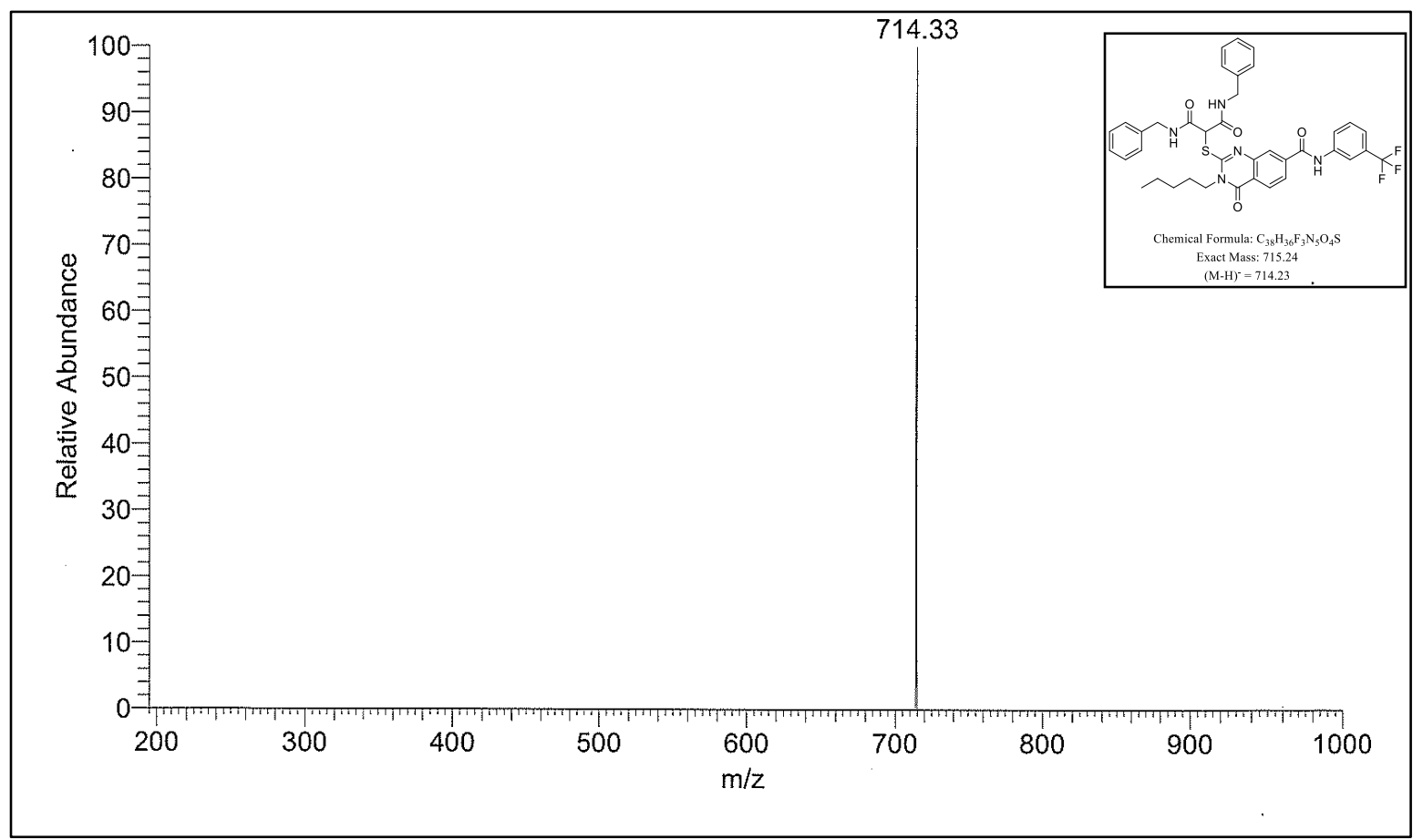

Figure S12: Mass spectrum of compound 3 . 


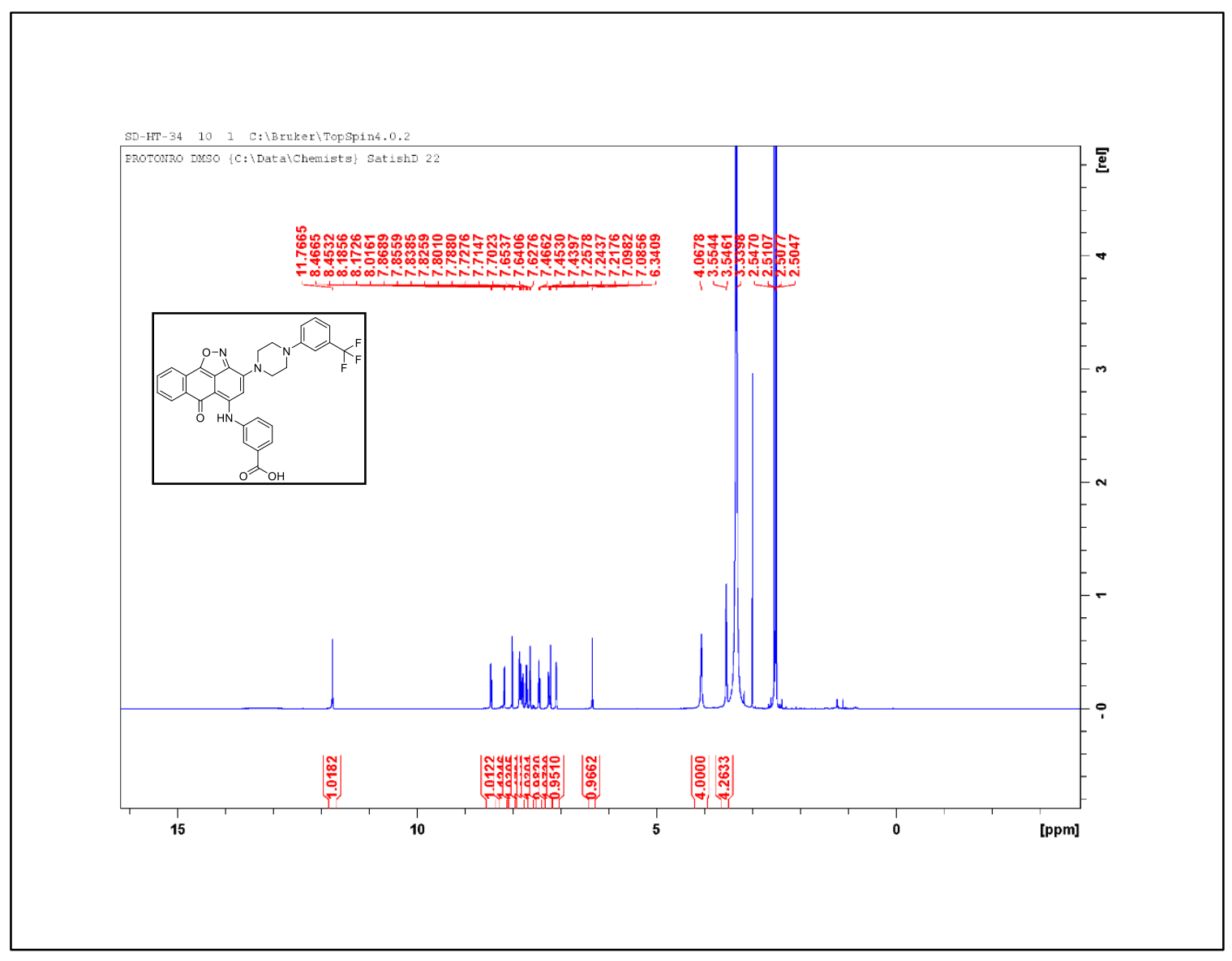

Figure S13: NMR spectrum of compound 5.

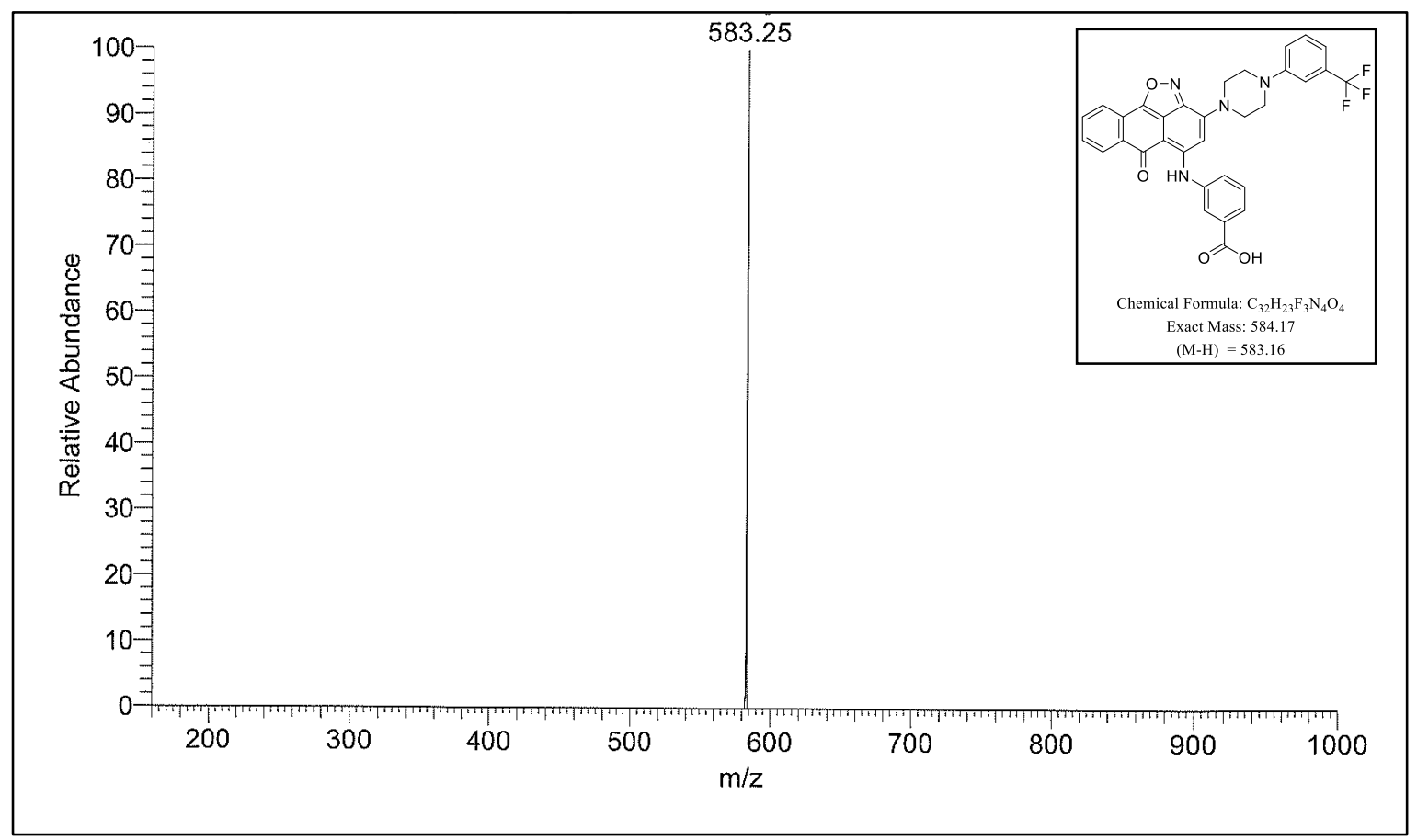

Figure S14: Mass spectrum of compound 5. 


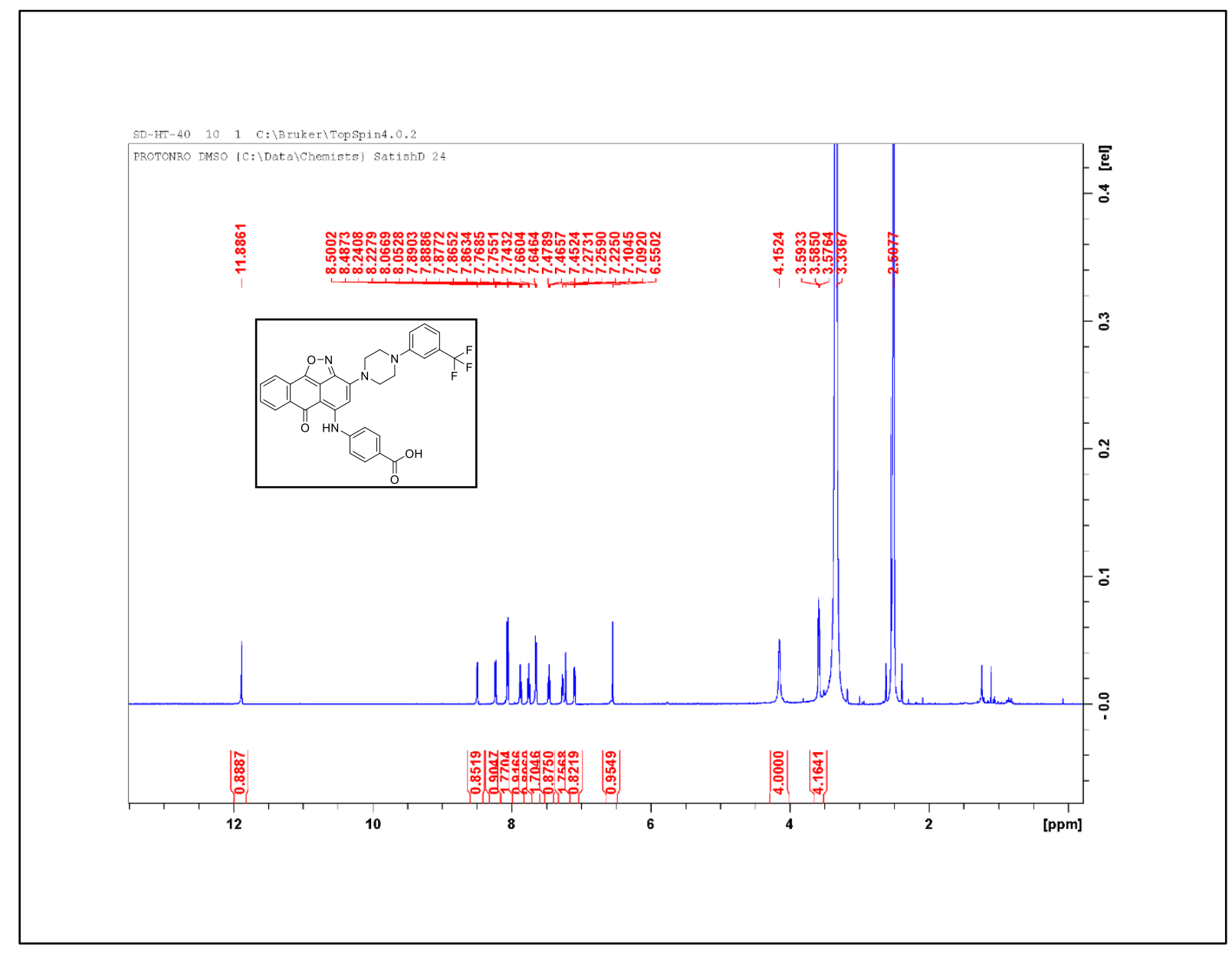

Figure S15: NMR spectrum of compound 7.

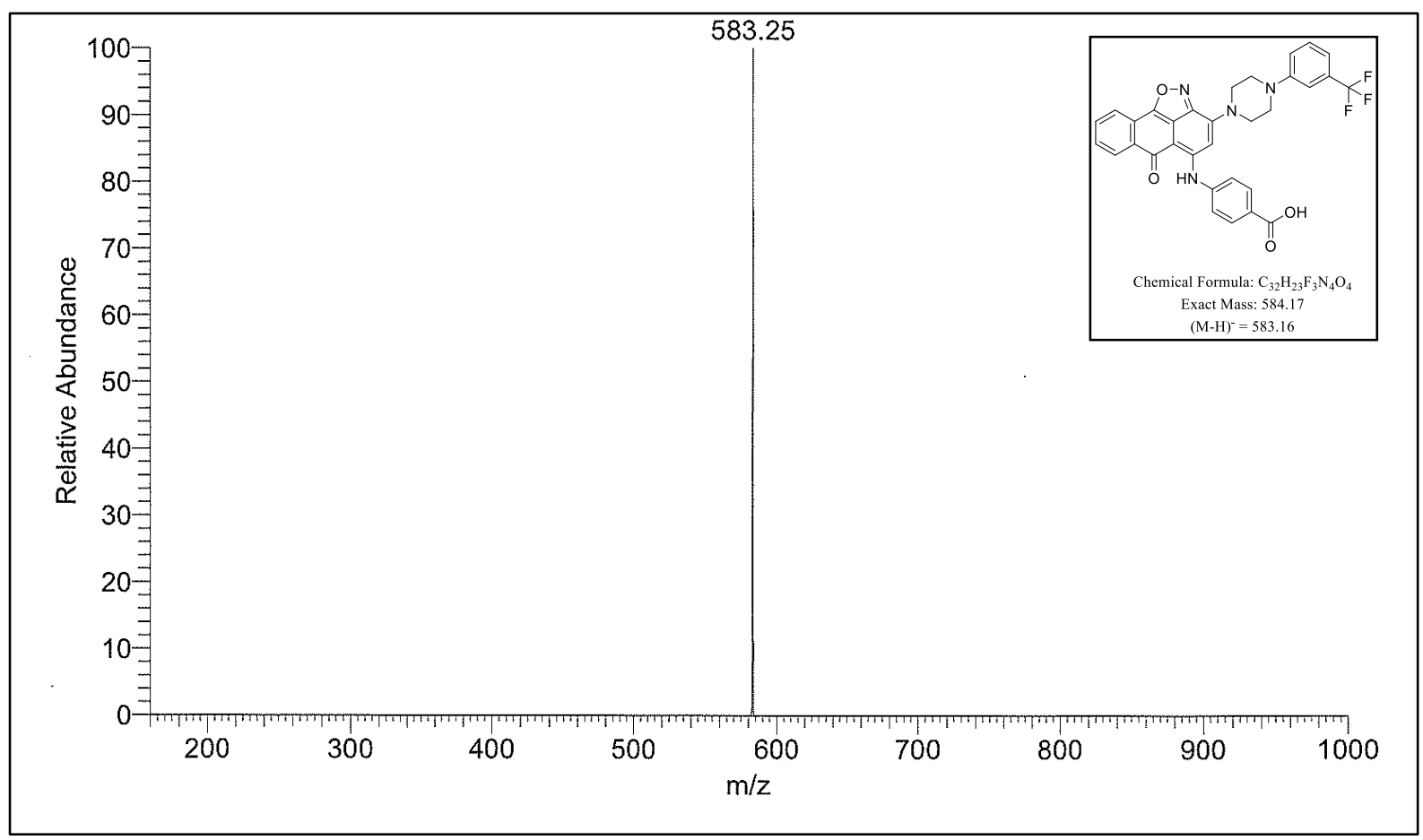

Figure S16: Mass spectrum of compound 7. 


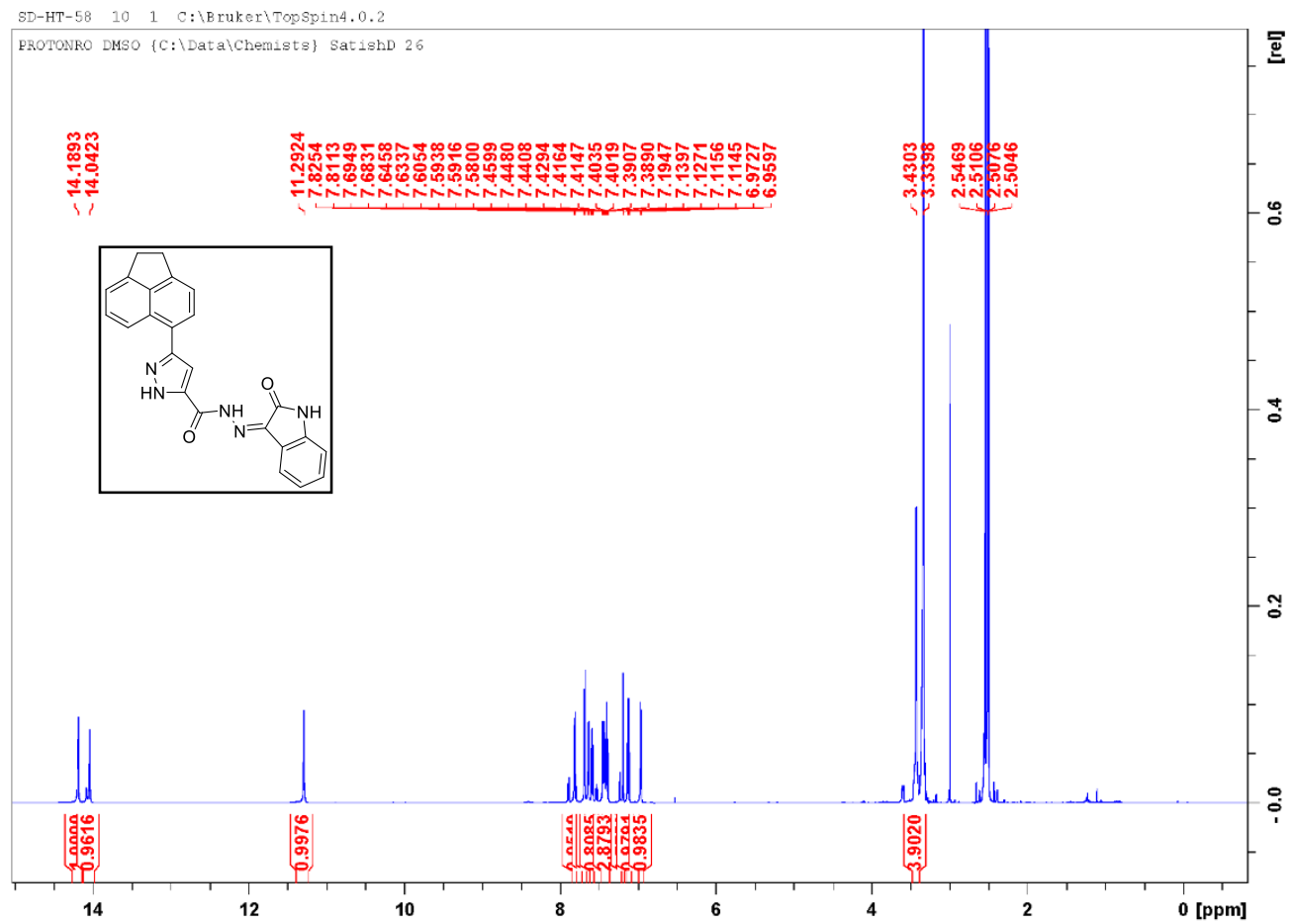

Figure S17: NMR spectrum of compound 9.

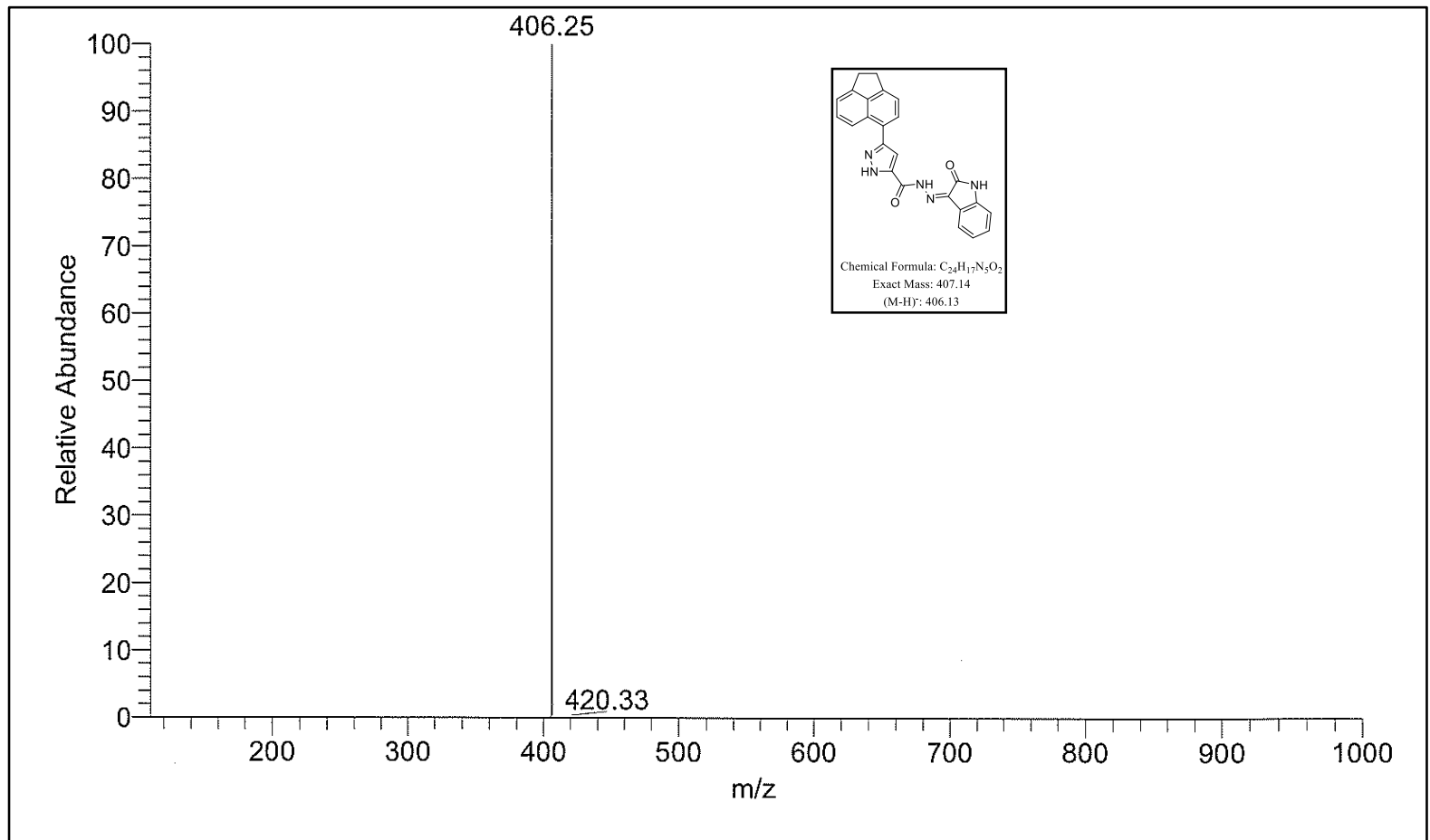

Figure S18: Mass spectrum of compound 9. 


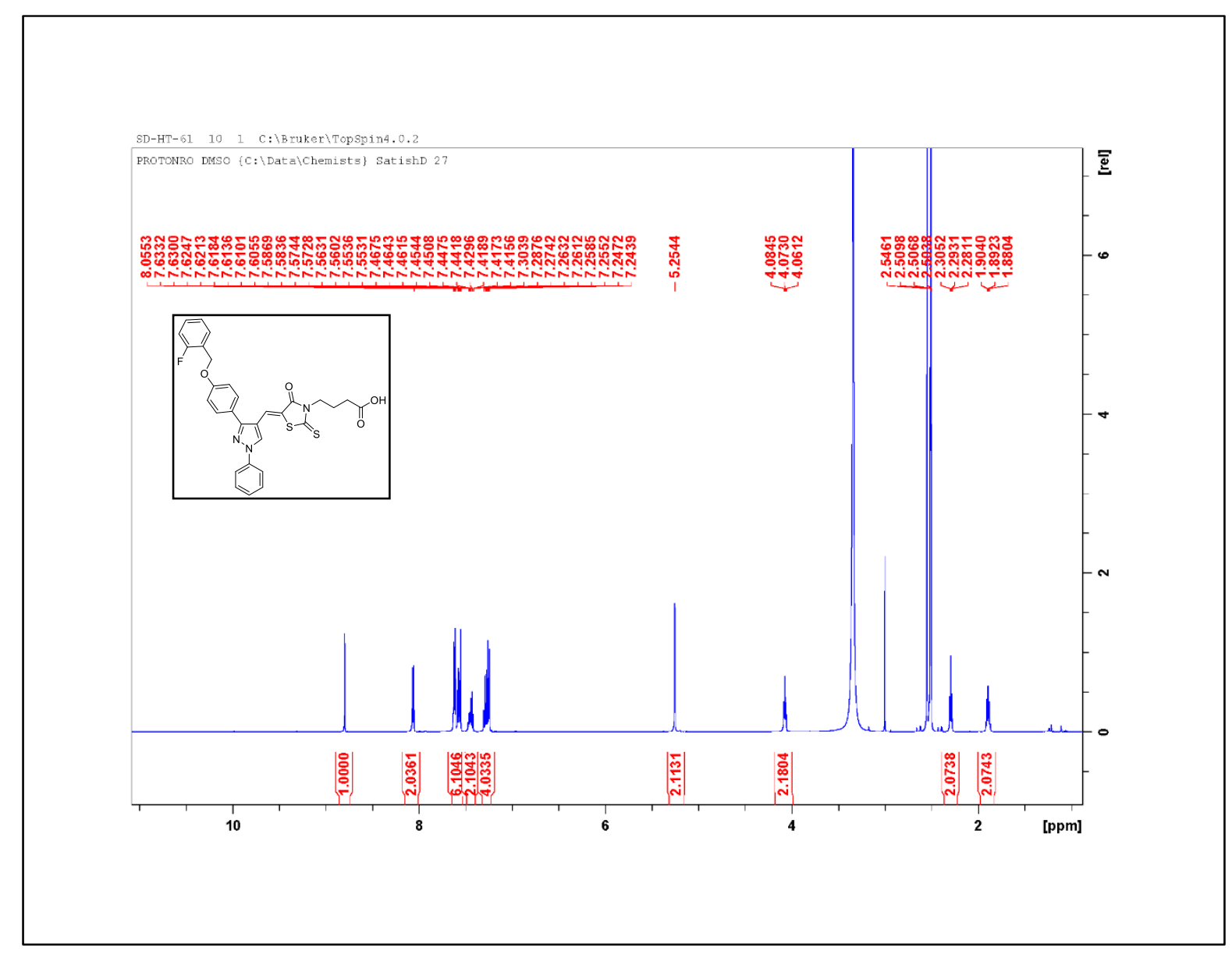

Figure S19: NMR spectrum of compound 13.

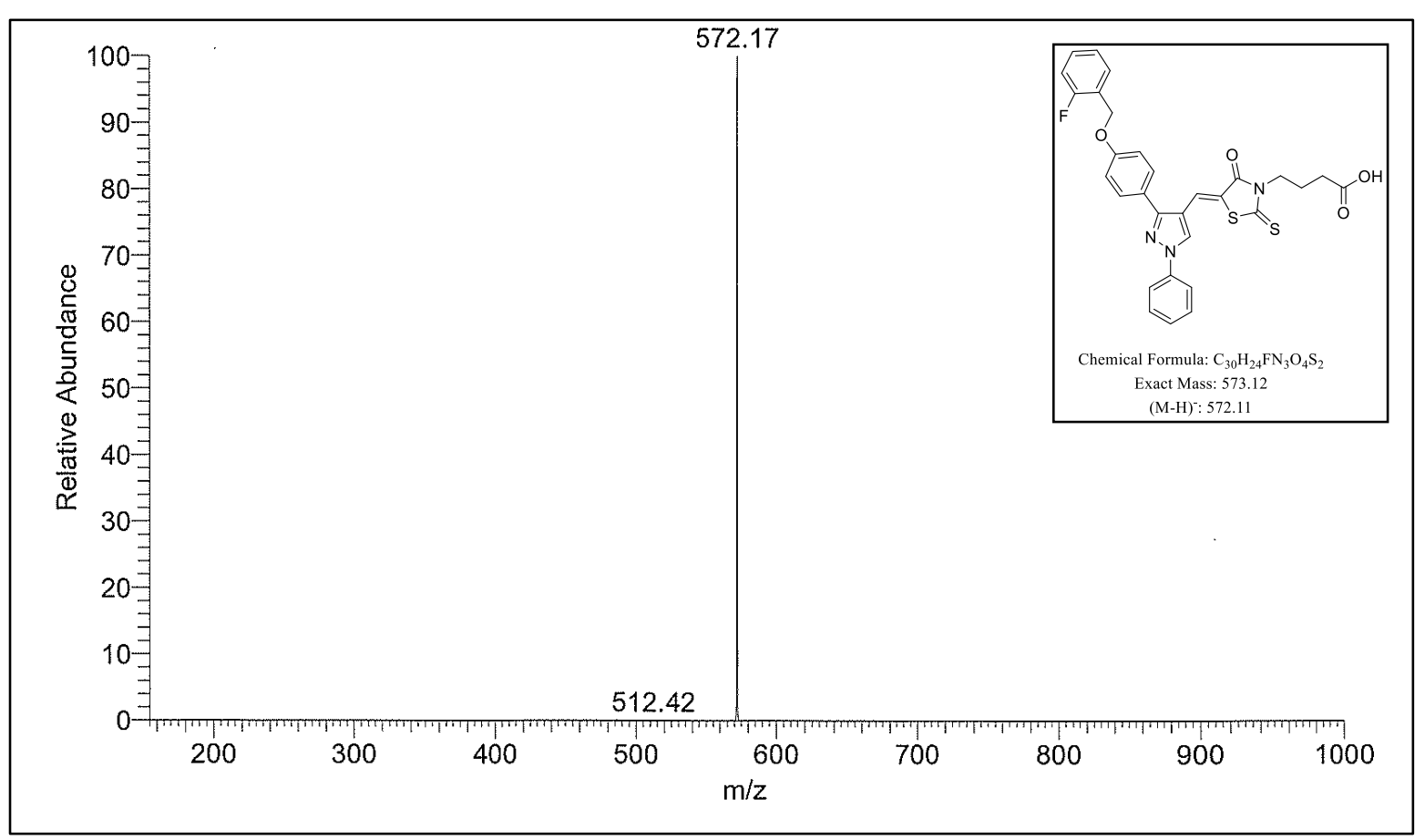

Figure S20: Mass spectrum of compound 13. 


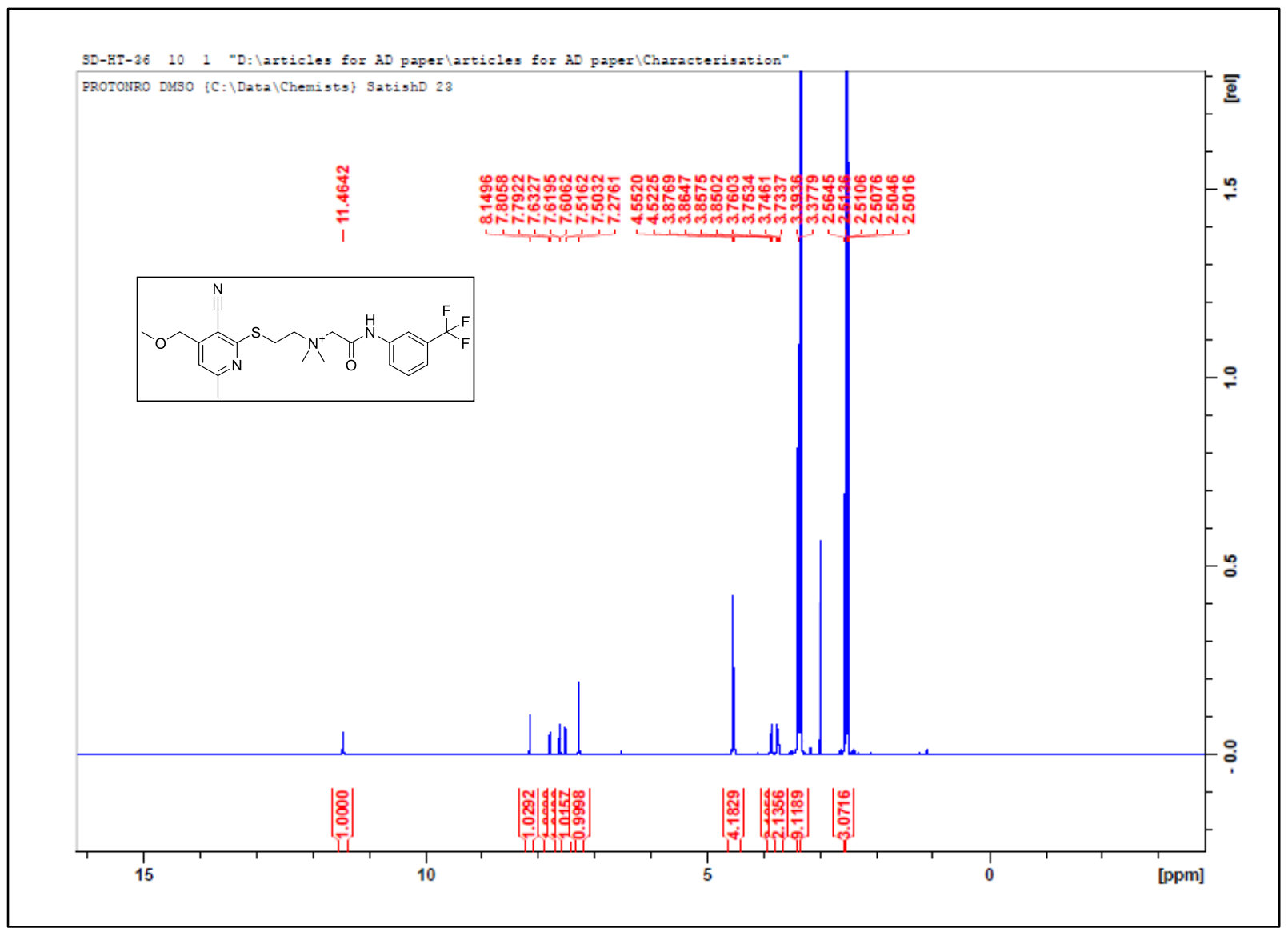

Figure S21: NMR spectrum of compound 18.

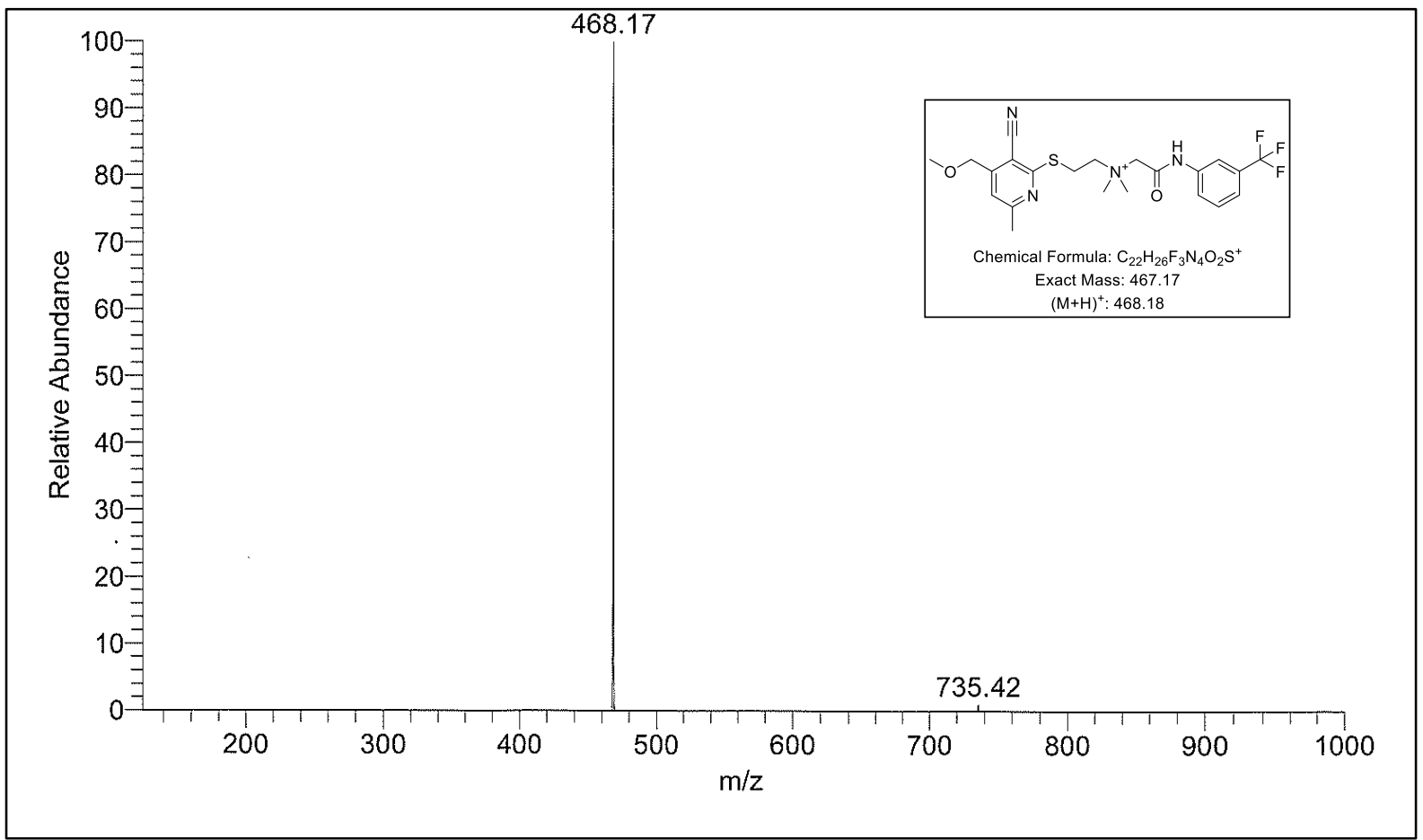

Figure S22: Mass spectrum of compound 18. 